\title{
EFFECT OF TRANSITION ELEMENTS ADDITIONS ON MICROSTRUCTURE AND TENSILE PROPERTIES OF A SECONDARY Al-7Si-Mg CAST ALUMINIUM ALLOY
}

\author{
Chrispin Ouko Zamzu ${ }^{1, *}$, Dr. Thomas Ochuku Mbuya ${ }^{1,2}$, \\ Dr. Christiaan Adika Adenya ${ }^{1,3}$, Timothy Ngigi ${ }^{3}$ \\ ${ }^{1}$ Department of Mechanical Engineering, Pan African University Institute \\ for Basic Sciences, Technology and Innovation, Kenya. \\ ${ }^{2}$ Department of Mechanical and Manufacturing Engineering, \\ University of Nairobi, Kenya. \\ ${ }^{3}$ Department of Mechanical Engineering, Jomo Kenyatta \\ University of Agriculture and Technology, Kenya. \\ *Corresponding Author
}

DOI: https://doi.org/10.51193/IJETSI.2021.6501

\begin{abstract}
The economic and environmental benefits of recycling aluminium alloys have increased the need to consider re-designing the alloys. The key challenge in recycling Al alloys is the varied chemical composition of the Al scrap. The effect of $\mathrm{Ti}, \mathrm{Sr}, \mathrm{Cu}$ and transition elements $\mathrm{Zr}$ and $\mathrm{V}$ additions on tensile properties of secondary cast $356 \mathrm{Al}-\mathrm{Si}$ alloy has been investigated with the aim of designing and producing premium automotive parts such as cylinder heads. The secondary cast $356 \mathrm{Al}-\mathrm{Si}$ alloy (base alloy) and its variant $356+0.5 \mathrm{Cu}+\mathrm{X}(\mathrm{X}=0.15 \% \mathrm{Ti}+$ $0.15 \% \mathrm{Zr}+0.25 \% \mathrm{~V}+0.015 \% \mathrm{Sr}$ ) was cast, HIP ped and $\mathrm{T} 6$ heat treated. There was notable improvement in the ultimate tensile strength (UTS) and Yield strength (YS) of the base alloy upon addition of the elements. At room temperature, the UTS improved from $224 \mathrm{MPa}$ to 279.3 $\mathrm{MPa}$ while the YT improved from $210 \mathrm{MPa}$ to $268 \mathrm{MPa}$. At high temperature $\left(237^{\circ} \mathrm{C}\right)$, the UTS and YT improved from $149 \mathrm{MPa}$ to $186 \mathrm{MPa}$ and from $122 \mathrm{MPa}$ to $167 \mathrm{MPa}$ respectively. These improvements in strengths were however accompanied by a decrease in percent elongation, from $5 \%$ to $4.4 \%$ and from $8 \%$ to $6.8 \%$, at room and high temperatures respectively. The decrease in ductility with the element addition can be attributed to the increased amount of course brittle intermetallic phases. At high temperature $\left(237{ }^{\circ} \mathrm{C}\right)$, the strengthening phases in the base alloy undergo Ostwald ripening thus resulting in lower UTS and YT. On the other hand, the micro
\end{abstract}


sized tri-aluminide phases are stable at high temperature $\left(237^{\circ} \mathrm{C}\right)$ explaining the substantial improvement in yield strength of $36.9 \%$.

Keywords: Al-Si alloys, Heat Treatment, Microstructure, Tensile properties.

\section{INTRODUCTION}

Al-Si alloys have become a suitable alternative to cast iron in the fabrication of automobile chassis and powertrain components e.g. wheels, cylinder heads, engine blocks and pistons. This has been driven by the continuous need to reduce vehicle weight, increase fuel efficiency, improve vehicle performance and reduce $\mathrm{CO}_{2}$ emissions alongside conservation of the environment [1], [2]. Al-Si alloys have attractive properties which include, high specific strength and stiffness, excellent thermal conductivity, good wear resistance, good recyclability and castability [3]-[6].

To improve on efficiency and performance, modern automotive engines require high operating temperatures $\left(>250^{\circ} \mathrm{C}\right)$ and pressure $(>180$ bar) [7], [8]. These operating conditions subject the engine components to thermomechanical fatigue. High temperatures (above $200^{\circ} \mathrm{C}$ ) also lead to a decline in the strength of the conventional Al-Si-Cu, Al-Si-Mg and Al-Si-Cu-Mg alloys. This is due to the rapid coarsening (Ostwald ripening) and dissolution of the strengthening phases $\mathrm{Al}_{2} \mathrm{Cu}, \mathrm{Mg}_{2} \mathrm{Si}$ and/or $\mathrm{Al}_{2} \mathrm{CuMg}$ [2], [4], [9]-[13]. According to Knipling [14], for effective high temperature performance of $\mathrm{Al}$ alloys, the alloying elements should have low solid solubility and diffusivity in the $\mathrm{Al}$ matrix. Transition elements such as $\mathrm{Ti}, \mathrm{Zr}, \mathrm{V}$, and $\mathrm{Cr}$ have been reported to be the best candidates for the formation of thermally stable phases [2], [8], [14]. These transition elements precipitate in the form of $\mathrm{Al}_{3} \mathrm{X}$-trialuminide phases of cubic $\mathrm{Ll}_{2}$ structure (chemically and structurally analogous to $\mathrm{Ni}_{3} \mathrm{Al}$ in the $\mathrm{Ni}$-based superalloys) and tetragonal structures $\mathrm{DO}_{22} / \mathrm{DO}_{23}$ [1], [8], [14].

The role of these transition elements in cast Al-Si alloys has recently been a subject of research [1]-[4], [11], [14]-[18]. Shaha et al. [3], [19] and Elhadari [11] reported that micro-additions of $\mathrm{Cr}, \mathrm{Zr}$, Ti and $\mathrm{V}$ significantly improved the fatigue life, yield strength (YS) and ultimate tensile strength (UTS) of Al-7Si-Cu-0.5Mg alloy compared to that of A356-T6 alloys both at room and high temperatures. Zamani et al. [4] stated that addition of $\mathrm{Zr}, \mathrm{Ni}, \mathrm{Ti}, \mathrm{V}$ and $\mathrm{Cr}$ to Al-10Si alloy resulted in a significant improvement in tensile strength at $250^{\circ} \mathrm{C}$, but at the expense of ductility. They attributed the reduction in ductility to the presence of coarse brittle phases such as $(\mathrm{AlSi})_{3}(\mathrm{TiZr}),(\mathrm{AlSi})_{3}(\mathrm{CrVTi}), \mathrm{AlNbTiZr}$ and AlSiV.

These improvements in mechanical properties are attributed to the precipitation strengthening by thermally stable nano-sized $\mathrm{Al}_{3}(\mathrm{Cr} / \mathrm{Ti} / \mathrm{Zr} / \mathrm{V})$-trialuminide precipitates, which are uniformly distributed in the aluminium matrix. These precipitates effectively hinder the movement of 
dislocations during tensile loading resulting in an improvement of the alloy strength [1]-[4], [11], [14]-[18]. The improvement in the mechanical properties Al-Si alloys containing micro additions of $\mathrm{Ti} / \mathrm{Zr} / \mathrm{V}$ has also been associated to their grain refining effect [2], [16], [18], [20][25]. However, Elhadari [11] observed that minor additions $(<0.25 \mathrm{wt}$. \%) of $\mathrm{Zr}$ and $\mathrm{V}$ yielded minimal grain refinement and that for effective grain refinement, the levels of $\mathrm{Zr}$ should be increased to $\sim 0.3-\sim 0.69$ wt. $\%$.

Previous works involving transition element additions have majorly concentrated on primary Al alloys [4], [11], [14]-[18]. The ecological and economic benefits of recycling aluminium alloys [26] has seen a lot of attention directed towards the possibility of using secondary aluminium alloys in producing premium automotive components (e.g. wheels, engine blocks, pistons and cylinder heads). However, the effect of transition elements on the microstructure and mechanical properties of secondary Al-Si alloys, that generally have higher impurity metal content, is not well understood. This work therefore seeks to investigate the effect of a combined element addition of $\mathrm{Ti}, \mathrm{Sr}, \mathrm{Zr}, \mathrm{V}$ and $\mathrm{Cu}$ on the microstructure and mechanical properties of secondary 356 alloys.

\section{EXPERIMENTS}

The Secondary cast 356 Al-Si alloy used in this work was obtained from casting after-life aluminium wheels. The alloy was melted and poured into a permanent mould and upon solidification, a bar casting obtained as shown in Figure 1. Optical Emission Spectroscopy (OES) was used to obtain the chemical compositions of the base alloy and the modified alloy. The various elements were added using master alloys (Al-10 wt\% Sr, Al-15 wt.\%Ti, Al-5 wt.\%V, Al10 wt. $\% \mathrm{Zr}$, and $\mathrm{Al}-50 \mathrm{wt} . \% \mathrm{Cu}$ ) to the base alloy. The chemical compositions are given in Error! Reference source not found.. Before specimens were prepared for testing, the castings were subjected to HIPping (holding at $520^{\circ} \mathrm{C}$ and $100 \mathrm{MPa}$ for 3 hours) followed by T6 heat treatment (solutionizing at $500{ }^{\circ} \mathrm{C}$ for alloys without $\mathrm{Cu}$ addition and $540{ }^{\circ} \mathrm{C}$ for $\mathrm{Cu}$-rich alloys, quenching in hot water at $60^{\circ} \mathrm{C}$ and immediate aging at $190^{\circ} \mathrm{C}$ for 100 hours followed by air-cooling). 


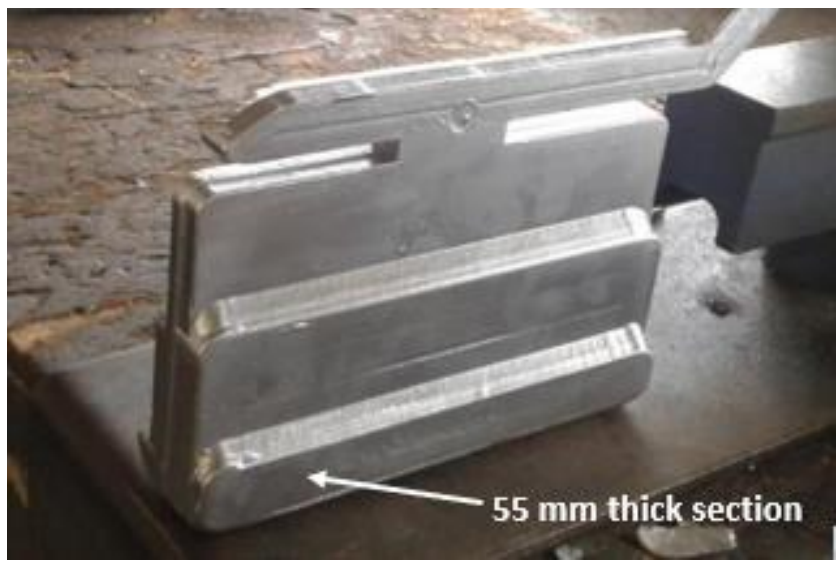

Figure 1: The bar casting obtained after the melt had solidified inside the permanent mould.

Table 1: Chemical composition (in wt.\%) of secondary 356 cast aluminium base alloy with transition element modification.

\begin{tabular}{lccccccccccc}
\hline Alloy & Si & Cu & Mg & Fe & Mn & Cr & Ti & Zr & V & Sr & Al \\
\hline 356 (Base alloy) & 6.95 & 0.0887 & 0.445 & 0.210 & 0.158 & 0.0174 & 0.0589 & 0.0040 & 0.0072 & 0.0009 & Bal \\
\hline 356+0.5Cu+X & 6.67 & 0.5611 & 0.533 & 0.192 & 0.117 & 0.070 & 0.160 & 0.102 & 0.219 & 0.0156 & Bal
\end{tabular}

$\mathrm{X}=0.15 \% \mathrm{Ti}+0.15 \% \mathrm{Zr}+0.25 \% \mathrm{~V}+0.015 \% \mathrm{Sr}$

Tensile tests were performed on an Instron 300DX universal testing machine at room temperature $\left(25^{\circ} \mathrm{C}\right)$ and high temperature $\left(237^{\circ} \mathrm{C}\right)$. The tensile specimen dimensions were as shown in Figure 2. Three specimens were tested for each condition.

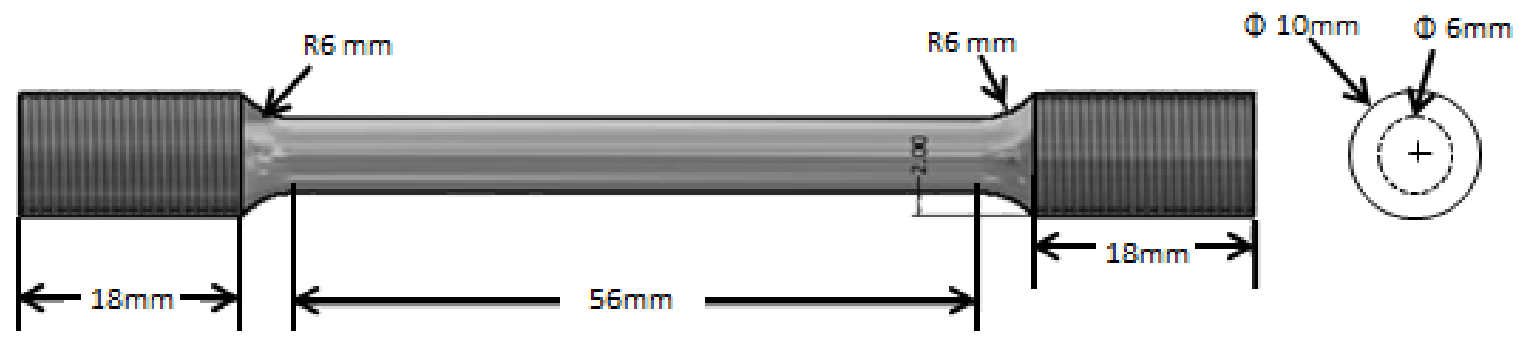

Figure 2: Tensile test specimen dimensions.

Microstructural characterization was performed on specimens obtained from tensile specimens after testing. Metallography involved polishing specimens to a $0.05 \mu \mathrm{m}$ OPS finish using standard grinding and polishing procedures. Scanning Electron Microscopy (SEM) was conducted using a Carl Zeiss LEO 1525 Field Emission Gun SEM at an accelerating voltage of $20 \mathrm{kV}$, a beam current of $10 \mu \mathrm{A}$ and a working distance of $15 \mathrm{~mm}$. 


\section{RESULTS AND DISCUSSION}

\subsection{Microstructure}

The base alloy 356 had an unmodified microstructure with irregular eutectic Si particles and a small number intermetallics as shown in Figure 3a. The microstructures of the modified alloy had a larger proportion of intermetallics as shown in Figure 3. The Si particles in the microstructure of the alloy were not fully modified despite the addition of Sr. The addition of $\mathrm{Zr}$, $\mathrm{V}$, and $\mathrm{Cu}$ however caused an increased amount of intermetallics.
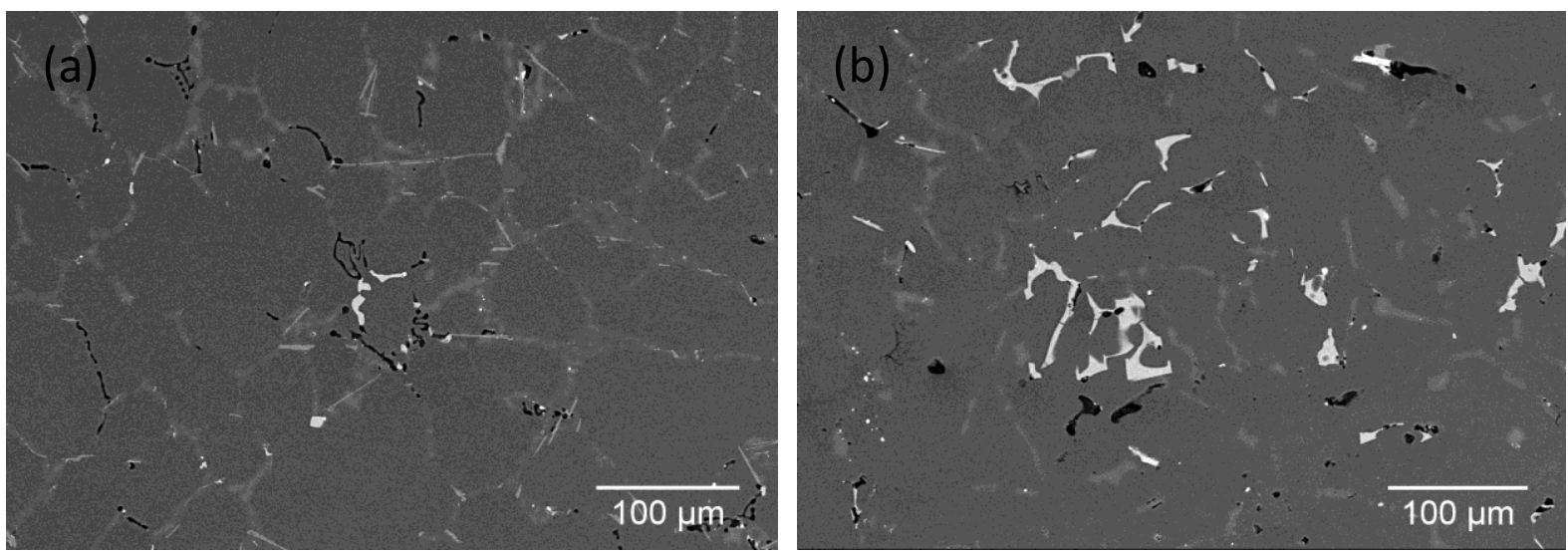

Figure 3: Microstructure of (a) the secondary 356 alloy and

(b) the modified $356+0.5 \mathrm{Cu}+\mathrm{X}$ alloy.

\subsection{Tensile Properties}

The results obtained from room temperature and high temperature $\left(237^{\circ} \mathrm{C}\right)$ tensile tests are shown in Figure 4. The tensile properties obtained from the results are shown in Table 2. 


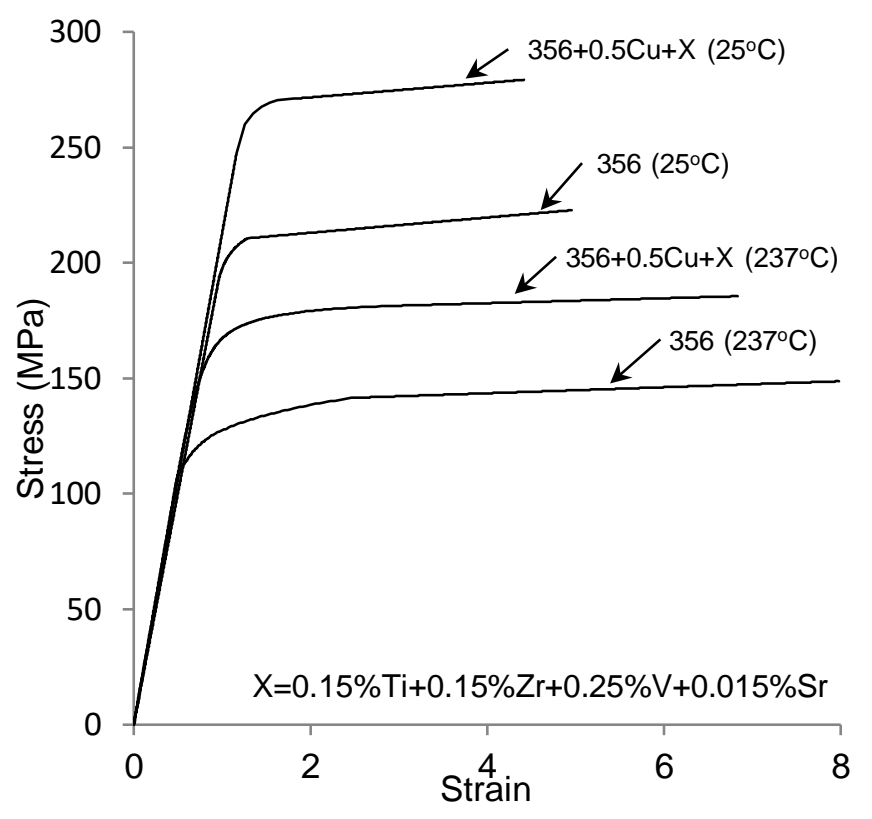

Figure 4: Tensile test results of the secondary 356 base alloy and the modified $356+0.5 \mathrm{Cu}+\mathrm{X}$ alloy.

Table 2: Room and high $\left(237^{\circ} \mathrm{C}\right)$ temperature tensile properties of the investigated alloys.

\begin{tabular}{|l|l|l|l|l|}
\hline & Tensile property & $\mathbf{3 5 6}$ & $\mathbf{3 5 6 + 0 . 5 C u + X}$ & Percent increase \\
\hline \multirow{2}{*}{$\begin{array}{l}\text { Room } \\
\text { Temperature } \\
\left(25^{\circ} \mathrm{C}\right)\end{array}$} & UTS $(\mathrm{MPa})$ & 224 & 279.3 & 24.7 \\
\cline { 2 - 5 } & YS(MPa) & 210 & 268 & 27.6 \\
\cline { 2 - 5 } & \%Elongation & 5 & 4.4 & -12 \\
\hline \multirow{2}{*}{$\begin{array}{l}\text { Tigh } \\
\text { Temperature } \\
\left(237^{\circ} \mathrm{C}\right)\end{array}$} & UTS $(\mathrm{MPa})$ & 149 & 186 & 24.8 \\
\cline { 2 - 5 } & YS $(\mathrm{MPa})$ & 122 & 167 & 36.9 \\
\cline { 2 - 5 } & $\%$ Elongation & 8 & 6.8 & -15 \\
\hline
\end{tabular}

As shown in Figure 4 and Table 2, the base alloy (alloy 356) has a room temperature ultimate tensile strength (UTS) of $224 \mathrm{MPa}$ and a $0.2 \%$ proof stress or yield strength (YS) of $210 \mathrm{MPa}$. The addition of $\mathrm{Ti}, \mathrm{Sr}, \mathrm{Cu}$ and transition elements $\mathrm{Zr}$ and $\mathrm{V}$ improves the UTS to $279.3 \mathrm{MPa}$ and the YS to $268 \mathrm{MPa}$. This shows a substantial increase of $24.7 \%$ and $27.6 \%$ for UTS and YS respectively. However, this increase in strength is accompanied by a $12 \%$ decrease in percent elongation from $5 \%$ to $4.4 \%$. 
Figure 4 and Table 2 also show that the base alloy (alloy 356) has a high temperature $\left(237^{\circ} \mathrm{C}\right)$ ultimate tensile strength of $149 \mathrm{MPa}$ and a yield strength of $122 \mathrm{MPa}$. The modified alloy has an improved UTS of $186 \mathrm{MPa}$ and a YS of $167 \mathrm{MPa}$. This shows a substantial increase of $24.8 \%$ and $36.9 \%$ for UTS and YS respectively. This increase in strength is also accompanied by a $15 \%$ decrease in percent elongation from $8 \%$ to $6.8 \%$.

The improvement in room temperature UTS and YS can mainly be attributed to the modification of the microstructure of base alloy 356 , solid solution strengthening due to a higher amount of dissolved solutes and the presence of strengthening precipitates such as trialuminide precipitates [1]-[4], [11], [14]-[18]. These micro-sized trialuminides are distributed in the aluminium matrix and they effectively impeded dislocations movement during the tensile deformation. These phases are stable at high temperature and can be attributed to the substantial increase in yield strength at $237^{\circ} \mathrm{C}$ of $36.9 \%$ [1][3], [4], [11], [28].

The ductility of the alloy was observed to generally decrease with element addition. This is attributed to the increased amount of coarse brittle intermetallic phases. The pronounced brittle failure of the modified alloy as opposed to the base alloy is illustrated in Figure 5 that shows SEM images of the fracture surfaces of failed tensile specimens for the base alloy (Fig 5a and 5c) and modified alloy (Fig 5b and 5d) at both room temperature and high temperature. It is clear that the base alloy shows a significant dimpled fracture surfaces at both room temperature (Fig 5a) and at high temperature (Fig $5 \mathrm{c}$ ). The modified alloy however shows a significant amount of cleavage fracture at both room temperature (Fig 5b) and high temperature (Fig 5d). 


\section{International Journal of Engineering Technology and Scientific Innovation}

ISSN: 2456-1851

Volume: 06, Issue: 05 "September-October 2021"
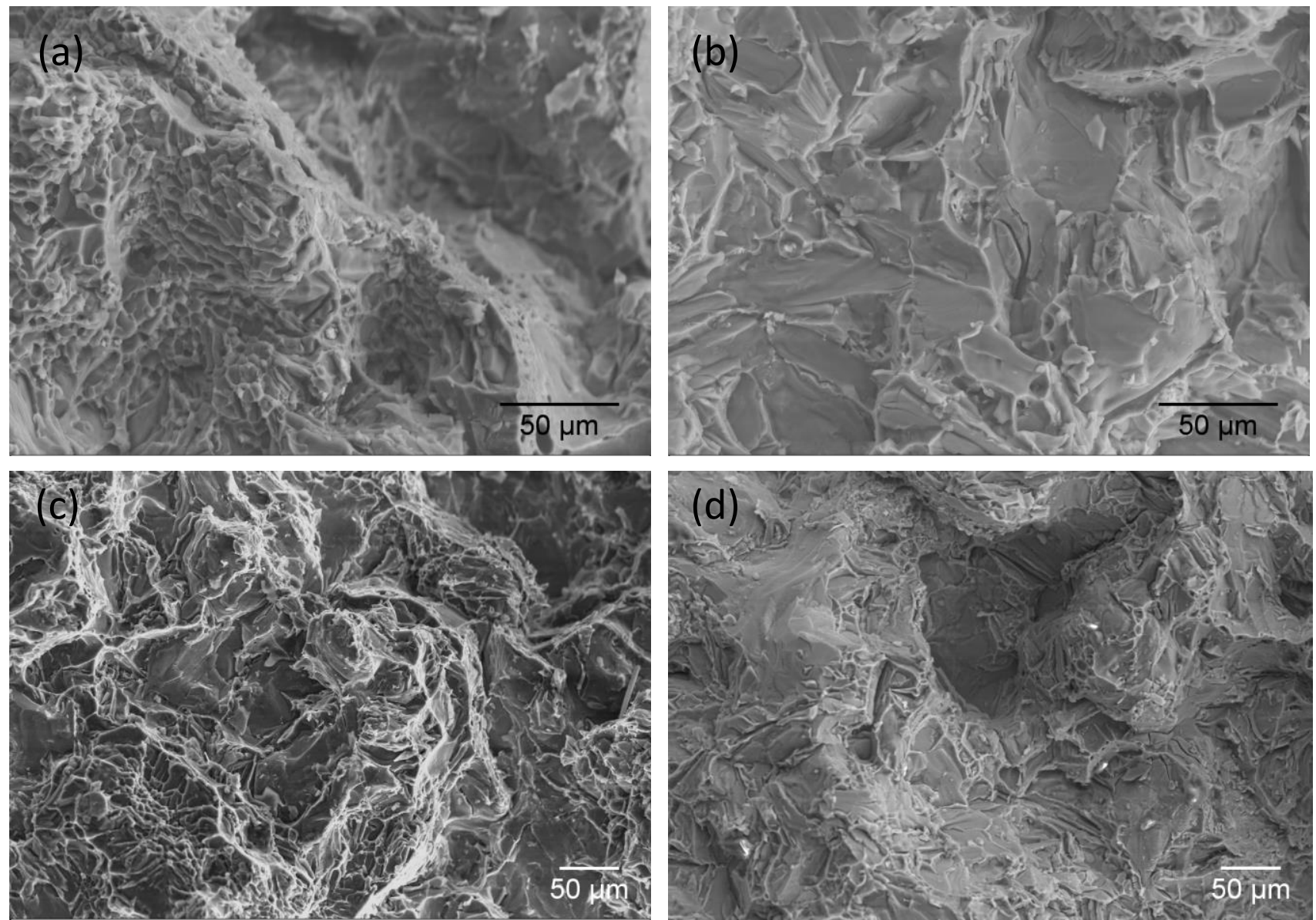

Figure 5: SEM images of the fracture surfaces of failed tensile specimens for the base alloy at room temperature (Fig 5a) and high temperature (Fig 5c) and the modified alloy at room temperature (Fig 5b) and high temperature (Fig 5d).

\section{CONCLUSION}

This work has demonstrated the effect of combined addition of $\mathrm{Ti}, \mathrm{Zr}, \mathrm{V}, \mathrm{CR}$ and $\mathrm{Cu}$ on the microstructure and tensile properties of secondary $356 \mathrm{Al}-\mathrm{Si}$ alloys.

a. The microstructure of base alloy 356 was unmodified with irregular eutectic Si particles and a small number of intermetallics while that of $356+0.5 \mathrm{Cu}+\mathrm{X}$ had larger intermetallics.

b. The values of UTS and YS at both room and high temperatures $\left(237^{\circ} \mathrm{C}\right)$ improved with the addition of $\mathrm{Ti}, \mathrm{Sr}, \mathrm{Cu}$ and transition elements $\mathrm{Zr}$ and $\mathrm{V}$. At room temperature, there was a $24.7 \%$ and $27.5 \%$ increase in UTS and YT respectively while at high temperature $\left(237^{\circ} \mathrm{C}\right)$, the UTS and YT increased by $24.8 \%$ and $36.9 \%$ respectively. These tri- 
International Journal of Engineering Technology and Scientific Innovation

ISSN: 2456-1851

Volume: 06, Issue: 05 "September-October 2021"

aluminide precipitates formed are stable at high temperature $\left(237^{\circ} \mathrm{C}\right)$ and can explain the substantial increase in $\mathrm{YT}$ at $237^{\circ} \mathrm{C}$ of $36.9 \%$.

c. The decrease in percent elongation by $12 \%$ and $15 \%$ at room and high temperatures respectively can be attributed to the increased amount of course brittle intermetallic phases.

d. This work has demonstrated that secondary Al-Si alloys with minor transition element adjustment possesses better tensile properties at high temperatures and thus can redesigned to withstand the harsh operating conditions in the automotive engine.

e. Further research work should be conducted to investigate the fatigue crack behaviour of the secondary 356 alloy with transition element additions at elevated temperatures where the engine components are subjected to thermomechanical fatigue.

\section{ACKNOWLEDGEMENTS}

The authors wish to thank the National Research Fund (NRF) for their financial assistance to the ongoing research work.

\section{REFERENCES}

[1] C. Frank, S. Dimitry, S. Sugrib, and C. Daolun, "Development of High Temperature Aluminum Alloys for Automotive Powertrain," Adv. Mater. Process., vol. 174, no. March, pp. 17-20, 2016.

[2] J. Rakhmonov, G. Timelli, and F. Bonollo, "The Effect of Transition Elements on HighTemperature Mechanical Properties of Al-Si Foundry Alloys-A Review," Adv. Eng. Mater., vol. 18, no. 7, pp. 1096-1105, 2016, doi: 10.1002/adem.201500468.

[3] S. K. Shaha, F. Czerwinski, W. Kasprzak, J. Friedman, and D. L. Chen, "Microstructure and mechanical properties of Al-Si cast alloy with additions of Zr-V-Ti," Mater. Des., vol. 83, pp. 801-812, 2015, doi: 10.1016/j.matdes.2015.05.057.

[4] M. Zamani, L. Morini, L. Ceschini, and S. Seifeddine, "The role of transition metal additions on the ambient and elevated temperature properties of Al-Si alloys," Mater. Sci. Eng. A, vol. 693, no. January, pp. 42-50, 2017, doi: 10.1016/j.msea.2017.03.084.

[5] Q. Zhang, Z. Zuo, and J. Liu, "High-temperature low-cycle fatigue behaviour of a cast Al12Si-CuNiMg alloy," Fatigue Fract. Eng. Mater. Struct., vol. 36, no. 7, pp. 623-630, 2012, doi: 10.1111/ffe.12029.

[6] F. M. Mbuya, T. O, Odera, B. O., Ng'ang'a, S. P., and Oduori, "Effective recycling of cast aluminium alloys for small foundries," J. Agric. Sci. Technol., vol. 12, no. 2, pp. 162-181, 2010.

[7] W. Kasprzak, B. S. Amirkhiz, and M. Niewczas, "Structure and properties of cast Al-Si based alloy with $\mathrm{Zr}-\mathrm{V}-\mathrm{Ti}$ additions and its evaluation of high temperature performance," $J$. 
International Journal of Engineering Technology and Scientific Innovation

ISSN: 2456-1851

Volume: 06, Issue: 05 "September-October 2021"

Alloys Compd., vol. 595, pp. 67-79, 2014, doi: 10.1016/j.jallcom.2013.11.209.

[8] M. Javidani and D. Larouche, "Application of cast Al-Si alloys in internal combustion engine components," Int. Mater. Rev., vol. 59, no. 3, 2014, doi: 10.1179/1743280413Y.0000000027.

[9] Y. C. Tzeng, C. T. Wu, C. H. Yang, and S. L. Lee, "Effects of trace Be and Sc addition on the thermal stability of Al-7Si-0.6Mg alloys," Mater. Sci. Eng. A, vol. 614, pp. 54-61, 2014, doi: 10.1016/j.msea.2014.07.013.

[10] S. K. Shaha, F. Czerwinski, W. Kasprzak, J. Friedman, and D. L. Chen, "Monotonic and cyclic deformation behavior of the Al-Si-Cu-Mg cast alloy with micro-additions of Ti, V and Zr," Int. J. Fatigue, vol. 70, pp. 383-394, 2015, doi: 10.1016/j.ijfatigue.2014.08.001.

[11] H. A. Elhadari, H. A. Patel, D. L. Chen, and W. Kasprzak, "Tensile and fatigue properties of a cast aluminum alloy with Ti, $\mathrm{Zr}$ and V additions," Mater. Sci. Eng. A, vol. 528, no. 28, pp. 8128-8138, 2011, doi: 10.1016/j.msea.2011.07.018.

[12] W. Kasprzak, D. Emadi, M. Sahoo, and M. Aniolek, "Development of Aluminium Alloys for High Temperature Applications in Diesel Engines," Mater. Sci. Forum, vol. 618-619, no. April, pp. 595-600, 2009, doi: 10.4028/www.scientific.net/MSF.618-619.595.

[13] C. Jeong, "High Temperature Mechanical Properties of Al-Si-Mg- $(\mathrm{Cu})$ Alloys for Automotive Cylinder Heads," Mater. Trans., vol. 54, no. 4, pp. 588-594, 2013, doi: 10.2320/matertrans.M2012285.

[14] K. E. Knipling, D. C. Dunand, and D. N. Seidman, "Criteria for developing castable, creep-resistant aluminum-based alloys - A review," International Journal of Materials Research, vol. 97, no. 3. pp. 246-265, Mar. 2006, doi: 10.3139/146.101249.

[15] S. K. Shaha, F. Czerwinski, W. Kasprzak, J. Friedman, and D. L. Chen, "Improving HighTemperature Tensile and Low-Cycle Fatigue Behavior of Al-Si-Cu-Mg Alloys Through Micro-additions of Ti, V, and Zr," Metall. Mater. Trans. A Phys. Metall. Mater. Sci., vol. 46, no. 7, pp. 3063-3078, Jul. 2015, doi: 10.1007/s11661-015-2880-х.

[16] M. Rahimian, S. Amirkhanlou, P. Blake, and S. Ji, "Nanoscale Zr-containing precipitates; a solution for significant improvement of high-temperature strength in $\mathrm{Al}-\mathrm{Si}-\mathrm{Cu}-\mathrm{Mg}$ alloys," Mater. Sci. Eng. A, vol. 721, no. February, pp. 328-338, 2018, doi: 10.1016/j.msea.2018.02.060.

[17] J. Hernandez-Sandoval, G. H. Garza-Elizondo, A. M. Samuel, S. Valtiierra, and F. H. Samuel, "The ambient and high temperature deformation behavior of Al-Si-Cu-Mg alloy with minor Ti, Zr, Ni additions," Mater. Des., vol. 58, pp. 89-101, Jun. 2014, doi: 10.1016/j.matdes.2014.01.041.

[18] E. Kilinc, N. Kiremitci, Y. Birol, and E. Dokumaci, "Effect of Vanadium and Zirconium Additions on Mechanical Properties and Microstructure of Gravity Die-Cast AlSi9Cu2 Alloy Cylinder Heads," Int. J. Met., pp. 1-9, Jun. 2018, doi: 10.1007/s40962-018-0238-z. 
International Journal of Engineering Technology and Scientific Innovation

ISSN: 2456-1851

Volume: 06, Issue: 05 "September-October 2021"

[19] S. K. Shaha, F. Czerwinski, W. Kasprzak, J. Friedman, and D. L. Chen, "Effect of Cr, Ti, $\mathrm{V}$, and $\mathrm{Zr}$ Micro-additions on Microstructure and Mechanical Properties of the Al-Si-CuMg Cast Alloy," Metall. Mater. Trans. A Phys. Metall. Mater. Sci., vol. 47, no. 5, pp. 2396-2409, May 2016, doi: 10.1007/s11661-016-3365-2.

[20] B. S. Murty, S. A. Kori, and M. Chakraborty, "Grain refinement of aluminium and its alloys by heterogeneous nucleation and alloying," Int. Mater. Rev., vol. 47, no. 1, pp. 329, Feb. 2003, doi: 10.1179/095066001225001049.

[21] Y. Meng, J. Cui, Z. Zhao, and Y. Zuo, "Effect of vanadium on the microstructures and mechanical properties of an Al-Mg-Si-Cu-Cr-Ti alloy of 6XXX series," J. Alloys Compd., vol. 573, pp. 102-111, Oct. 2013, doi: 10.1016/j.jallcom.2013.03.239.

[22] S. Wang, Y. Liu, H. Peng, X. Lu, J. Wang, and X. Su, "Microstructure and Mechanical Properties of Al-12.6Si Eutectic Alloy Modified with Al-5Ti Master Alloy," Adv. Eng. Mater., vol. 19, no. 12, pp. 1-5, 2017, doi: 10.1002/adem.201700495.

[23] D. G. Mallapur, K. R. Udupa, and S. A. Kori, "Influence of Grain Refiner and Modifier on the Microstructure and Mechanical Properties of a356 Alloy," Int. J. Eng. Sci. Technol., vol. 2, no. 9, pp. 4487-4493, 2010.

[24] B. Baradarani and R. Raiszadeh, "Precipitation hardening of cast Zr-containing A356 aluminium alloy," Mater. Des., vol. 32, no. 2, pp. 935-940, 2011, doi: 10.1016/j.matdes.2010.08.006.

[25] R. Mahmudi, P. Sepehrband, and H. M. Ghasemi, "Improved properties of A319 aluminum casting alloy modified with Zr," Mater. Lett., vol. 60, no. 21-22, pp. 26062610, Sep. 2006, doi: 10.1016/j.matlet.2006.01.046.

[26] S. K. Das, "Designing Aluminium Alloys for a Recycling Friendly World," in Materials Science Forum, 2006, vol. 519-521, pp. 1239-1244, doi: 10.4028/www.scientific.net/MSF.519-521.1239.

[27] ASTM B 557M - 02a, "Standard test methods of tension testing wrought and cast aluminum and magnesium alloys products ASTM B557-10," Stand. test methods Tens. Test. wrought cast aluminum-and magnesium-alloy Prod., vol. 02, pp. 1-15, 2010, doi: 10.1520/B0557-10.2.

[28] S. K. Shaha, F. Czerwinski, W. Kasprzak, J. Friedman, and D. L. Chen, "Effect of Cr, Ti, $\mathrm{V}$, and $\mathrm{Zr}$ Micro-additions on Microstructure and Mechanical Properties of the Al-Si-CuMg Cast Alloy," Metall. Mater. Trans. A Phys. Metall. Mater. Sci., vol. 47, no. 5, pp. 2396-2409, May 2016, doi: 10.1007/s11661-016-3365-2. 